\title{
Brand as Promise
}

\author{
Vikram R. Bhargava ${ }^{1}$. Suneal Bedi ${ }^{2}$
}

Received: 1 September 2020 / Accepted: 30 April 2021 / Published online: 15 May 2021

(c) The Author(s) 2021, corrected publication 2021

\begin{abstract}
Brands are widely regarded as a constellation of shared associations surrounding a company and its offerings. On the traditional view of brands, these associations are regarded as perceptions and attitudes in consumers' minds in relation to a company. We argue that this traditional framing of brands faces an explanatory problem: the inability to satisfactorily explain why certain branding activism initiatives elicit the moralized reactive attitudes that are paradigmatic responses to wrongdoing. In this paper, we argue for a reframing of brands that calls for viewing brands as a series of normatively binding expectations that are ethically akin to promises. Our promissory framing of brands avoids the explanatory problem, illuminates a number of ethical requirements on branding, and reconceptualizes the role of brand managers.
\end{abstract}

Keywords Brand activism $\cdot$ Marketing ethics $\cdot$ Theory of brands $\cdot$ Promise $\cdot$ Brand as promise

On the traditional view of brands held by marketing scholars (and also implicit in most empirical marketing research), a brand is the constellation of shared associations surrounding a company and its offerings. These associations are understood to be the perceptions and attitudes (including, beliefs, desires, mental images, etc.) that consumers hold in their minds in relation to a company (hereafter, "the traditional view") (Aaker, 1991; Keller, 2003; Keller \& Lehmann, 2006). For example, the Disney brand is the shared set of perceptions and attitudes such as fun, colorful, imaginative, princess, family-friendly, cheerful, among other perceptions and attitudes that consumers have in their minds of Disney (Jean, 2015). So, on the traditional view, a brand is the shared series of perceptions and attitudes that come to mind in relation to a firm and its offerings.

This traditional view of brands has the advantage of being simple and lending itself to straightforward empirical

Vikram R. Bhargava

vbhargava@scu.edu

Suneal Bedi

sbedi@iu.edu

1 Department of Management and Entrepreneurship, Leavey School of Business, Santa Clara University, 500 El Camino Real, Santa Clara, CA 95053, USA

2 Department of Business Law \& Ethics, Kelley School of Business, Indiana University, 1309 E. 10th Street, Bloomington, IN 47405, USA investigation. If the shared associations that constitute brands are understood merely as a set of perceptions and attitudes that consumers have of the firm, then one can learn all there is to learn about a brand by studying the shared perceptions and attitudes consumers have of the firm. Decades of marketing research has taken this very approach (Aaker, 1991; Farris et al., 2010; Keller, 1993; Kotler, 1991; Krishnan, 1996; Ravi et al., 2005; Schmitt, 2012; Sürücü et al., 2019).

Although the traditional view gets part of the story right and has a number of advantages, it faces a difficulty: an explanatory problem. In particular, it has difficulty explaining why consumers sometimes express distinctively moralized sentiments when firms change their brand associations. For example, when companies rebrand in ways that consumers do not expect, consumers sometimes overtly express indignation and resentment, which Strawson (1962) famously characterizes as the moral reactive attitudes, toward the company. ${ }^{1}$ These sorts of responses were seen

\footnotetext{
1 The now enormous scholarly conversation surrounding the moral reactive attitudes (notably, resentment and indignation) are due to the Oxford philosopher P.F. Strawson's highly influential article, Freedom and Resentment (1962). Resentment and indignation are types of hostile emotions, and thought to be part of what is involved when we blame one another. Crucially, resentment and indignation are distinct from general emotional states such as a feeling of anger because they are directed, and aren't just an overall affect. Resentment is widely regarded as the apt response to being wronged, and indignation is regarded as a sort of vicarious response, one that is on behalf of another person who was wronged.
} 
after Nike's endorsement of Colin Kaepernick (an NFL quarterback who famously kneeled during the national anthem as a symbolic statement against police brutality toward persons of color in the United States) and Gillette's recent advertisement campaign that challenged certain conventional understandings of masculinity. The framing of brands under the traditional view results in a theory of brands that does not have the resources to satisfactorily explain why consumers might have these normatively charged responses, nor why, in some circumstances, these responses might be appropriate.

Given this difficulty, it is worth exploring alternative conceptualizations of brands. One alternative conception of brands that marketing scholars (Abela \& Murphy, 2008; Knapp, 2000; Levitt, 1981), business ethicists (Murphy et al., 2005), and practitioners (Pimentel, 2007; Satell, 2010) have occasionally gestured at involves understanding brands as promises. For example, in marketing scholarship, Pearson (2006: 385) notes, "frankly, a brand is a promise," and Barney (2014: 24) notes that a "brand is a promise made by a firm to its customers." Other marketing scholars have used phrases like "delivering on the brand promise" (Punjaisri \& Wilson, 2017: 91). In business ethics, some have argued "the phrase 'a brand is a promise' is a common one among marketing practitioners," and that the brand's associations "can be considered to be a set of promises that the firm makes" (Murphy et al., 2005: 105). ${ }^{3}$ And practitioners, too, have sometimes adopted the language of promises: "There wasn't a brand consultant in the world who didn't [claim that brands are promises] on a slide in their pitch deck" (Novosedlik, n.d.). (See also Pimentel, 2007; Satell, 2010).

Unfortunately, apart from brief mentions of brands as promises or metaphorical comparisons to brands involving promises, few have carefully investigated how the notion of promises might inform our understanding of brands. ${ }^{4}$ Although these scholars seem to recognize the intuition that brands are akin to promises, they have not taken seriously the analytical conditions of promises and the normative implications that follow from identifying these same analytical conditions in brands. In business ethics, a prominent textbook on the ethics

\footnotetext{
2 This citation is due to Anker et al. (2012).

3 Scholars have recognized the importance of normative ethics to questions in marketing (Dunfee et al., 1999; Laczniak \& Murphy, 2019; Smith, 1995).

${ }^{4}$ One notable exception is Anker et al.'s (2012) article, which provides a more robust conceptualization of brands and promises. And they too appeal to Scanlon's expectation view of promises. Our account, in contrast to theirs, is decidedly a normative business ethics account, and one that carefully delineates how exactly brands are ethically akin to promises and also articulates managerial implications, including the moral constraints on rebranding and the reconceptualization of the role of brand managers.
}

of marketing devotes only one paragraph to brands as promises (Murphy et al., 2005). Moreover, other marketing ethicists have spoken only in broad general terms about how ethical frameworks can apply to marketing practices (Laczniak \& Murphy, 2019; Smith, 1995). And practitioners have strictly focused on the instrumental benefits of keeping one's brand promise. So, with rare exception, few have taken seriously the claim that brands are ethically akin to promises. ${ }^{5}$

In this paper, we offer a sustained articulation of brands as promises. In particular, we grant that brands involve a series of perceptions and attitudes surrounding a company and its offerings (as is the case under the traditional view), but argue that they also have a robust normative core, one that is constituted with a series of normatively binding expectations (hereafter, "the promissory core"). Crucially, these normatively binding expectations are governed by the same moral principles that imbue promissory practices with ethical significance (Scanlon, 1990, 1998). Thus, we broaden the traditional view's framing of brands by offering a richer normative conceptualization of brands that explicitly recognizes brands as ethically akin to promises. ${ }^{6}$

Notably, if the traditional view is supplemented with the promissory core we characterize, it allows for a theory of brands that avoids the explanatory problem. This is because, we argue, the distinctively moralized responses in the wake of certain branding efforts (e.g., Nike's and Gillette's recent branding campaigns) are best understood as responses rendered appropriate by an act that is analytically akin to a broken promise.

\footnotetext{
5 The ethics of promising is a rich and active area of research (Darwall, 2009; Deigh, 2002; Gilbert, 1993, 2013; Habib, 2018; Heuer, 2012b, 2012a; Kolodny \& Wallace, 2003; Mason, 2005; Owens, 2007, 2008, 2006; Rawls, 1955; Scanlon, 1990, 1998; Sheinman, 2011; Shiffrin, 2008; Watson, 2004). Promising also has provided theoretical insight in other domains closely related to business ethics, especially to the philosophy of contracts (Fried, 2015). To date, however, there is no developed scholarly account in business ethics scholarship about how promises relate to branding.

${ }^{6}$ When we claim that brands are, ethically speaking, akin to promises, are we claiming that brands and promises are analogically or metaphorically related? Our view is neither that brands are analogously related to promises nor that they are a metaphorically related to promises. Rather, our point is that both brands and promises are governed by the same moral principle (i.e., the principle of fidelity, as we discuss further below), and this principle is what generates the promissory obligation. Here is an example of the type of relationship between brands and promises that we are characterizing: both lawyers and doctors, in virtue of the asymmetry of information brought about by expertise (among other reasons), are governed by fiduciary duties to clients and patients, respectively. This is not to say that lawyers and doctors are analogically or metaphorically akin, but rather that both professions possess the analytical features that generate fiduciary duties. Returning to our context, both brands and promises belong to the class of entities that possess the property of generating obligations in virtue of being governed by the same moral principle (i.e., the principle of fidelity). We are grateful to an anonymous reviewer for urging us to clarify this point.
} 
While we offer a reframing of the traditional view, and believe that doing so has both theoretical and practical advantages, we do not regard our view as radically revisionary. Branding is complex, messy, and touches various areas of research including marketing, psychology, sociology, philosophy, finance, data science, etc. Thus, developing a comprehensive theory of brands would be beyond the scope of this article-we do not regard ourselves as providing an exhaustive set of necessary and sufficient conditions for the concept of brands. Rather, we offer an account of an aspect of brandsits promissory core - that has largely been underexplored. Our promissory reframing of brands is both consistent with, and complementary to, the traditional view of brands.

But our promissory reframing of brands is not without consequence, given the normative significance of promises. This is because promises themselves are through and through a normative phenomenon: promises uncontroversially generate obligations. In other words, on all plausible accounts of the ethics of promising, it is wrong to break a promise (Habib, 2018; Heuer, 2012a, 2012b). The argument we advance is a simple one: brands are, ethically speaking, akin to promises. And, as we noted, an analytical feature of promises is that they generate obligations. Thus, we argue, brands generate obligations.

Several practical implications follow from our work. First, our promissory view shows how firms that intend to adopt strong, moral, political, or social stances [more generally termed, "brand activism" (Sarkar \& Kotler, 2018)]—like in the Nike and Gillette examples-face certain procedural requirements in their branding initiatives. Second, our theory reconceptualizes the role of brand managers by putting at the forefront the promissory core of brands. We show how brand managers face certain ethical constraints when rebranding in the wake of a PR crisis. To highlight this aspect of our account, we discuss the example of Blackwater-a private military corporation that faced a PR crisis for its role in a number of human rights violations during the 2003 Iraq War, which rebranded by merely renaming its organization "Xe", and subsequently "Academi" (Hudson, 2012).

We proceed as follows. "The Current Treatment of Brands and the Problem it Faces" introduces the traditional view and explains why it faces the explanatory problem. In "A Theory of Brand as Promise", we develop our promissory account of brands by drawing upon Scanlon's $(1990,1998,2001)$ influential expectation theory of promises. We show how supplementing the traditional view with a promissory core allows for a theory of brands that avoids the explanatory problem. "The Procedural Requirements for Rebranding" explores the procedural requirements that brand managers face when rebranding. "Reconceiving the Role of Brand Managers" highlights how our account reconceptualizes the role of brand managers. "Future Avenues of Research" provides several future avenues of research. We then conclude.

\section{The Current Treatment of Brands and the Problem it Faces}

The traditional view of brands understands brands as the constellation of shared associations surrounding a company and its offerings, where these associations are interpreted as the aggregate set of perceptions and attitudes that are prompted when a consumer sees, hears about, or comes into contact with a company and its offerings (Aaker, 1991; Keller, 1993, 2003; Keller \& Lehmann, 2006). Scholars sometimes refer to the concept of brand using multiple names, e.g., "brand image" or "brand meaning". For example, Keller (1993: 3) notes that brand image is "perceptions about a brand as reflected by the brand associations held in consumer memory." Brand meaning is the "information (e.g. attributes, beliefs, attitudes, or experiences) connected to the brand name in the memory" (Sjödin \& Törn, 2006: 33). For our purposes, what is significant is that most contemporary marketing scholars frame brands as simply shared associations of a company and its offerings in a consumer's mind, where these associations are interpreted as perceptions or attitudes-i.e., the traditional view.

Furthermore, the prevailing method to empirically assess brands is by identifying the types and strengths of these perceptions and attitudes consumers have of a company and its offerings (Agarwal \& Rao, 1996; Change, 2002; Herzog, 1963; Keller, 2003; Newman, 1957; Schmitt, 2012). For example, Keller's method for measuring brand ("customerbased brand equity model") is just that; it identifies the types, strengths, and distinctiveness of the perceptions and attitudes that consumers hold in their mind for a given company and its offerings. This form of measurement is shared by the International Organization for Standardization, which seeks to standardize the measurement of brand value and is embodied in their definition of what a brand is: "creating distinctive images and associations in the minds of stakeholders" (International Organization for Standardization, 2019 § 3.1). In effect, in both conceptual and empirical arguments, marketing scholars have historically treated brands as simply the totality of shared associations that consumers have in relation to the firm and its offerings, where these associations are understood as attitudes and perceptions.

We now turn to a weakness of a theory of brands understood exclusively through the lens of the traditional view: an explanatory problem.

\section{The Explanatory Problem}

The traditional view has an explanatory problem: it cannot satisfactorily explain the presence of certain distinctively moralized responses (e.g., expressions of resentment) to companies engaging in brand activism through their advertisement 
campaigns. For example, Nike controversially endorsed former NFL quarterback, Colin Kaepernick, in a recent marketing campaign. Kaepernick famously kneeled during the performance of the national anthem at the start of several football games in 2016 to draw attention to, and silently protest, the existence of structural race issues in the US criminal justice system. While this is clearly an important issue for the US to confront, many US citizens had negative reactions to Kaepernick's kneeling: they were outraged at Kaepernick's actions, arguing he should be sanctioned or fired, and that the NFL should institute a policy against kneeling (Griner, 2018). Kaepernick eventually left his team and sought a new team without success in March 2017 and, ultimately, brought an official grievance against the NFL for allegedly blackballing him once he became a free agent (Mather, 2019).

Subsequently, Nike released an advertisement with a photo of Kaepernick and the caption, "Believe in something. Even if it means sacrificing everything," and adopted Kaepernick as a spokesperson for their new "Just Do It" campaign (Draper \& Creswell, 2019), thereby endorsing Kaepernick's commitment to criminal justice reform. In response, many customers were morally outraged at Nike's decision to endorse Kaepernick, in part, because they did not think his initial kneeling was appropriate. Some of these consumers took to Twitter to denounce the brand saying things like Nike is "forc[ing] me to choose between my favorite shoes and my country," some burned Nike shoes/socks in protest (Gay, 2018; Sarkar \& Kotler, 2018), and still some, including various small cities and schools, boycotted Nike.

In another recent example, Gillette ran an advertisement that challenged conventional conceptions of masculinity that purportedly embodied aggressive and toxic ideals, while also accounting for their own role in promoting this conception of masculinity. In January 2019, in an ad lasting over 100 s, Gillette featured clips from their own past advertisements, in which Gillette itself had presented men in a positive light when they were behaving as bullies, displaying sexist and physically aggressive traits, and saying things like "boys will be boys," when wrestling. The 2019 ad then asked, "Is this the best a man can get?" (a play on their own, prior, branded slogan "The Best a Man Can Get"), while showing men behaving in more mature ways by preventing bullying, standing up for women, and being gentle with their children. According to the Gillette website (2019), the ad aimed to challenge the conventional conceptions of masculinity that Gillette itself had previously promoted (Topping et al., 2019).Although promoting less toxic masculine imagery may be laudable, the advertisement was ultimately met with severe backlash from consumers. Many claimed to boycott Gillette razors and criticized the ad for "jumping on the "men are horrible' campaign" (Topping et al., 2019). Celebrities like Piers Morgan even tweeted responses like, "I've used Gillette razors my entire adult life but this absurd virtue-signaling PC guff may drive me away to a company less eager to fuel the current pathetic global assault on masculinity. Let boys be damn boys. Let men be damn men" (Morgan, 2019). The magazine New American attacked Gillette for creating "false suppositions" in claiming that "men are the dangerous sex" (Topping et al., 2019).

The traditional view of brands cannot satisfactorily account for these moralized responses to Nike's and Gillette's advertising campaigns. Through the lens of the traditional view, a brand is a constellation of associations where these associations are merely a shared set of perceptions and attitudes consumers have of a company and its offerings. On the traditional view, in launching the Kaepernick advertisement campaign, Nike created certain perceptions and attitudes-including, but not limited to, race, criminal justice, kneeling, national anthems, and law enforcement - that may not previously have been associated with Nike. Similarly, Gillette might have created certain perceptions and attitudes pertaining to masculinity that were not previously there. But why would the mere creation of perceptions or attitudes with respect to a company elicit the moralized reactive attitudes, which are paradigmatically regarded as apt responses to wrongdoing (Strawson, 1962)? Through the lens of the traditional view, it's not clear why consumers would not simply replace their associations with the new ones Nike and Gillette promoted in their advertising, rather than issue characteristically moralized responses.

One might object that the traditional view does, after all, have the resources to fully account for the consumer responses in the Nike and Gillette cases by appealing to consumer preferences (Cheng et al., 2012; Trump, 2014). The defender might take the following approach: Once we acknowledge that consumers have preferences, then the consumer behavior in the Nike and Gillette cases can be straightforwardly explained. When Nike launched its Kaepernick campaign, some people simply disliked, for example, certain progressive ideals embodied in the campaign. ${ }^{7}$ Similarly, when Gillette launched its campaign, some people disliked, for example, what they regarded as undue political correctness. So, once we account for preferences, it seems we can explain the outrage in the Kaepernick and Gillette cases. When the consumers updated their associations (where the associations are understood as perceptions and attitudes) surrounding Nike and Gillette, some of the consumers-namely, the outraged consumers-strongly disliked these new associations. In other words, the consumer responses can be explained by an update of associations combined with negative preferences in relation to these new associations. Once preferences are accounted for, this appears to remedy the explanatory problem that arises when brands are understood through the lens of the traditional view.

Unfortunately, appeals to preferences do not satisfactorily remedy the explanatory problem for two reasons. First,

\footnotetext{
7 We use "disliked" here as a rough stand-in for possessing negative valences or contrary preferences.
} 
appeals to preferences threaten to prove too much. For example, if the negative responses to Nike were due only to the fact that Nike adopted a progressive brand activist campaign (and consumers simply had preferences against progressive stances), this does not explain why the vigorous response was to Nike, in particular. Many companies adopt progressive stances and consumers do not level comparably vigorous criticisms of the many brands that do so. There is a sense in which this was a unique response directed at Nike, in particular.

Second, if consumer reactions to Nike's political stance were best explained solely as a preferential difference, this would not explain why we saw distinctively moralized responses, such as the moral reactive attitudes (i.e., indignation and resentment) and protests. Presumably, if Nike changes its brand to something that consumers do not like, they could simply not consume Nike products going forward, in the same way that they might not consume other products they do not like. For this reason, even if a theory of brands seen through the lens of the traditional view appeals to preferences to explain the nature of consumer responses to certain branding activities, it falls short of satisfactorily explaining why distinctively moralized responses seem to accompany certain brand activism campaigns, such as in the Nike and Gillette cases.

This is not to say that preferences have no place in a comprehensive theory of brands; they surely do. Rather, our point is that a theory of brands seen through the lens of the traditional view, even once we acknowledge preferences, leaves an explanatory gap: why would the creation of perceptions or associations that weren't previously present generate responses typically reserved for wrongdoing? In the next section, we argue that the explanatory problem can be overcome once we acknowledge the promissory core of brands. In particular, we argue, brands can be framed and understood as a shared series of normatively binding expectations that are governed by the same ethical principles as promises.

\section{A Theory of Brand as Promise}

Before we articulate our promissory account of brands, it will be useful to briefly discuss the nature of promises. Promises take many forms. Most commonly, promises take the form of an utterance: for example, by saying, "I promise I will do X," this utterance, absent special circumstances, satisfies the conditions that generate an obligation to do X (hereafter, "promissory obligation"). However, for a promissory obligation to arise, the act need not always be expressed through an utterance. Certain acts generate the very same obligations that promises do: For instance, the act of sitting down and ordering food at a restaurant is a promise to pay for the meal, even if one never explicitly says, "I promise to pay for the meal." In other words, certain actions express that one is undertaking a promise, and as a result generates an obligation to perform the promised action.
What's special about promises is that by the mere fact of uttering a promise under certain conditions (or engaging in an action that expresses that one is undertaking a promise), one can bind oneself in ways that one is not ordinarily bound. For example, while picking up a friend from the airport is a nice thing to do, it is not something one is typically under a moral obligation to do (unlike, for example, the obligation not to unjustifiably harm others). However, if one promises to pick a friend up from the airport, one now is morally obligated to pick that friend up. In other words, promises are special in that they are voluntarily undertaken and generate obligations to perform an act that one would otherwise not be obligated to perform.

There are a number of accounts of promises: normative powers theories (e.g., Shiffrin's (2008)), conventionalist theories (e.g., Hume (2001); Rawls (1955)), and interpersonal theories (e.g., Darwall (2009); Gilbert (2013)). ${ }^{8}$ While each of these theories have significant pedigrees and prominent

\footnotetext{
${ }^{8}$ Philosophers writing on promises launch their discussions from the premise that, in ordinary circumstances, breaking a promise is wrong. We too take this as our starting point. The scholarly controversy surrounding promises arises with respect to the source and nature of the obligation to fulfill one's promises - this is to say, the debate is about why, and in virtue of what, it is wrong to break a promise. This debate was launched by Hume's seminal discussion of promising in which he famously observed that promises are "naturally something altogether unintelligible" (Cohon, 2006: 35) due to their ability to seemingly generate "a new obligation of morality on the person who promises and since this new obligation arises from his will; it is one of the most mysterious and incomprehensible operations that can possibly be imagined" (Heuer, 2012a: 832). Hume characterizes this notion of willing an obligation that was previously nonexistent as a "peculiar act of mind" (Cohon, 2006: 26), one that he regards as impossible. Hume thus concludes that promissory obligation must be an "artificial virtue," one that hinges on the presence of a social convention (Cohon, 2006: 26). So, on Hume's view, unlike "natural virtues" such as "parental dedication, gratitude, and humanity" (Cohon, 2020), the basis of promissory obligation hinges on not undermining the cooperative benefits that are realized through our promissory conventions (Deigh, 2002: 492). So, the requirement to keep one's promises on Hume's account is parasitic on the requirement to "contribute positively and importantly to the collective good of human beings" (Deigh, 2002: 492) and keeping one's promises is required because it helps preserve this practice that is in all of our interests. Rawls is a more recent defender of a conventionalist account of promises in which he argues that promissory obligation arises due to what he calls "the principle of fairness" (1999: 303-308). Rawls's grounds for the wrongness of breaking a promise can be understood as being grounded in the wrongness of free-riding (Scanlon, 1998: 296). Although there a number of criticisms of the conventionalist view, the chief criticism is that it does not correctly locate who is wronged when a promise is broken. Scanlon (1990, 1998), Kolodny and Wallace (2003), and others, object that conventionalist accounts of promises overlook their directed nature - that is, "the keeping of a promise is owed to the promisee" (Heuer, 2012a: 837), in particular. When John breaks his promise to Jane, it's not that John just wronged the moral community by lowering the efficacy of the institution of promising, but rather that he wronged Jane, specifically. This is evidenced by the fact that he owes Jane an apology, not the community at large (Kolodny \& Wallace, 2003: 126). Since our paper concerns the business ethics of branding, we do not delve into the debate surrounding whether the basis of promissory obligation is conventionalist, or other ongoing debates in the philosophy of promises.
} 
defenders (as well as their own difficulties), our preferred account of promising is T.M. Scanlon's $(1990,1998)$ influential expectation theory of promises. This is because while the expectation theory of promises is grounded in an independently plausible normative theory, it is also articulated in largely naturalistic terms and can thus provide a useful theory for future researchers to study the empirical dimensions of our theory of brands as promise. ${ }^{9}$

On Scanlon's view, "the wrong of breaking a promise and the wrong of making a lying promise are instances of a more general family of moral wrongs which are concerned not with social practices but rather with what we owe to other people when we have led them to form expectations about our future conduct" (1998: 296). Specifically, the expectation theory of promises holds that promises generate obligations when the "principle of fidelity" is satisfied:

Principle of Fidelity: "If (1) $A$ voluntarily and intentionally leads $B$ to expect that $A$ will do $X$ (unless $B$ consents to $A$ 's not doing so); (2) $A$ knows that $B$ wants to be assured of this; (3) $A$ acts with the aim of providing this assurance, and has good reason to believe that he or she has done so; (4) $B$ knows that $A$ has the intentions and beliefs just described; (5) $A$ intends for $B$ to know this, and knows that $B$ does know it; (6) $B$ knows that $A$ has this knowledge and intent, then, in the absence of special justification, $A$ must do $X$ unless $B$ consents to $X$ 's not being done" (Scanlon, 1990: 208). ${ }^{10}$

These conditions pick out the kind of activities that are governed by the principle of fidelity (including promises) and articulate the normative implications of any activity that satisfies these conditions. On Scanlon's account, promissory obligation is a "special case of a wider category of duties and obligations regarding the expectations that we lead others to form about what we intend to do" (1998: 295).

According to Scanlon's expectation theory of promises, the key value implicated in our promissory practices is the value of assurance-this is what justifies the principle of fidelity. To better understand the value of assurance that justifies the principle of fidelity (and in turn, renders promise keeping obligatory), it can be helpful to draw a contrast to a different sort of situation, one where promissory obligation

\footnotetext{
9 This taxonomy is due to Habib's (2018).

10 There are, of course, some criticisms of this account, e.g., Kolodny and Wallace's (2003); however, much of this criticism is about whether promissory obligation is exclusively grounded in the presence of certain social conventions. This issue, while of theoretical importance, does not bear significantly on our account, given our concern here is not the ultimate source of promissory obligation, but rather drawing attention to structural similarities between the principles that govern promises and branding activities.
}

is not generated, even if there may be a different sort of obligation generated. Consider a situation in which one has "intentionally or negligently led someone to expect that one is going to follow a certain course of action, $\mathrm{X}$, and one has good reason to believe that that person will suffer significant loss as a result of this expectation if one does not follow X" (Scanlon, 1998: 300-301) —in such a situation, one ought to take certain reasonable measures to prevent the loss in question-this is what Scanlon calls the "principle of loss prevention". Depending on the context, the specific reasonable measure to prevent the loss can range from warning the person that the expected action will not be performed to compensating that person for his or her loss (Scanlon, 1998: 301). ${ }^{11}$

But notice that the principle of fidelity that undergirds promissory obligation is importantly different from the principle of loss prevention. With promises, one cannot escape the obligation merely by warning the promisee that one has changed one's mind, or by compensating the promisee for the loss-both of those routes would be better than doing nothing, but nevertheless, in both cases, an obligation is still violated (Scanlon, 1998: 301). As Scanlon puts it, "the obligation one undertakes when one makes a promise is an obligation to do the thing promised, not simply to do it or to compensate the promisee accordingly...The central concern of the morality of promises is therefore with the obligation to perform; the idea of compensation is of at most secondary interest" (1998: 301). For this reason, to capture promissory obligation, one requires a stronger principle than the principle of loss prevention: this is precisely the role that the principle of fidelity fulfills. The principle of fidelity secures a more robust sort of assurance than what is secured by the weaker principle of loss prevention.

As noted, the obligation to comply with the principle of fidelity is grounded in the value of assurance. There are multiple reasons for caring about the value of assurance. One important reason is the ability to "rely on these assurances in deciding what to do" (Scanlon, 1998: 303), and wanting the freedom from worry that this assurance provides. Another reason to care about the value of assurance arises not from any experiential comfort the assurance provides, but rather, from the mere fact of "[wanting] certain things to happen... [promisees] want to be given assurances, and they care about whether these assurances are genuine" (Scanlon, 1998: 303). Crucially, because of the reasons promisees have for wanting assurance, this also gives reasons to prospective promisers to want to be able to deliver that assurance (Scanlon, 1998:

\footnotetext{
11 The specific loss prevention measure to pursue depends on factors such as the nature of what is being lost, the extent to which the person who brought about those expectations did so negligently, etc. For a more detailed discussion of this point, see Scanlon's (1998: 301).
} 
303). Thus, on Scanlon's account, the reasons both promisers and promisees have with respect to the value of assurance is what generates a duty to comply with the principle of fidelity.

Scanlon's expectation theory of promises is "widely influential" (Habib, 2018), having influenced a number of theoretical investigations, including the philosophy of cooperation (Tuomela, 2013), medical oaths (Sulmasy, 1999), and the ethics of migration (Hosein, 2019). Indeed, even critics of Scanlon's expectation theory have characterized it as "pioneering work" (Kolodny \& Wallace, 2003: 119) that has "reinvigorated debate about the nature and grounds" (Deigh, 2002: 483) of promissory obligation. We now turn our attention to how Scanlon's expectation theory informs our promissory account of brands.

On our promissory reframing of brands, brands are a constellation of normatively binding expectations (in virtue of satisfying the principle of fidelity). As Scanlon points out, uttering the words "I promise" is not a necessary part of generating the same obligation that is issued when uttering a promise: "It is enough that the conditions of intention and mutual knowledge specified in [the principle of fidelity] be fulfilled" (1998: 305) and that "the conditions of expectation and knowledge that [the principle of fidelity] specifies can be fulfilled in many ways other than by making a promise" (1998: 306). So, let's now turn to the conditions that the principle of fidelity articulates. We will illustrate how they are satisfied in branding processes using the example of the brand of the Volvo Group ("Volvo"). ${ }^{12}$

(1) A voluntarily and intentionally leads $B$ to expect that $A$ will do $X$ (unless $B$ consents to A's not doing so).

On our promissory account, when a firm creates or sustains a brand, this involves voluntarily and intentionally engendering a set of expectations surrounding what the firm will do. For example, the associations that make up Volvo's brand involves the series of expectations that Volvo intentionally and voluntarily creates, including, but not limited to, the expectation that it will prioritize the safety of its vehicles. In other words, Volvo intentionally and voluntarily creates the expectation that its cars are made to be among the safest in the industry, among other expectations.

(2) A knows that $B$ wants to be assured of this.

Firms know that consumers want assurance of the expectations they have created about their products or services. Assurance is "the value of having the mat-

\footnotetext{
12 The example of Volvo is commonly used in marketing scholarship (Dawar \& Lei, 2009; Mats, 2003; Tilley, 1999) and also referred to in Murphy et al.'s (2005) brief discussion of the relation between brands and promises.
}

ter settled" (Scanlon, 1990: 206), or alternatively, the value of being able to rely on the expected action, or not needing to devote further thought or worry to the matter at hand.

A prospective car buyer who is concerned about safety and has come to expect safety from Volvo wants assurance that this expectation is justified: this is, after all, the very reason for Consumer Reports, JD Power $\&$ Associates, and the widespread prevalence of consumer reviews. In short, firms know that consumers want assurance that the expectations they've come to form about a firm's product or service will not be unjustified and will accurately map onto what the firm will in fact do. Consumers don't want to have to devote further cognitive or monetary resources to investigate the justifiability of the expectation in question (in this case, the expectation that the car will be a safe one).

(3) A acts with the aim of providing this assurance, and has good reason to believe that he or she has done so.

Companies commonly act to assure consumers of the expectations they elicit. Sometimes this is done by imploring prospective consumers to look for a certain logo, slogan, or emblem. Other times, firms are even more explicit in the assurance they offer.

Volvo, too, acts with the aim of providing this assurance (i.e., about the expectation of safety in their vehicles) and has good reason to believe it has done so. Indeed, Volvo's website (2019) prominently notes, "Personal safety is at the heart of Volvo's purpose," and that its vision holds that "no one should be seriously injured or killed in a new Volvo car," and finally that "the guiding principle behind everything we make at Volvo therefore is, and must remain, safety."

Clearly, Volvo aims to assure consumers that their expectations of safety are well founded and that consumers need not devote further thought to this expectation. Given that firms also commonly hire large marketing teams to effectively provide this assurance, it is plausible that firms have good reason to believe that they have provided the assurance in question.

(4) B knows that $A$ has the intentions and beliefs just described.

Most consumers know that firms intend to assure them of the expectations they've formed and also realize that firms often believe they have given the assurance in question. Another way to put the point is that consumers realize that they are being marketed to in ways that seek to assure them. This plausibly qualifies 
as consumers knowing that firms have the intention and beliefs associated with aiming to provide assurance about their products or services. This condition is straightforwardly satisfied by the very nature of marketing: consumers know that firms intend to assure them that what they've come to expect about the firm's products or services are well justified. This is supported by a significant body of empirical research about consumer beliefs regarding company advertisements (Boush et al., 1994; Calfee \& Ringold, 1994; Coulter et al., 2001; Friestad \& Wright, 1995; Petty \& Cacioppo, 1986; Soh et al., 2009).

(5) A intends for $B$ to know this, and knows that $B$ does know it.

The very fact that logos, emblems, and other brand markers are often visible and sometimes even explicitly communicated assurances (e.g., Verizon's "the most reliable network") suggests that firms intend for consumers to know about the assurance they are attempting to provide through their logos, emblems, color schemes, markers, and communications (and also know that any consumer who comes across the logo or marker in question will know that that is their aim). In the case of Volvo, this is again clear with its public remarks to consumers. The Volvo website notes (2019), "Our focus on protecting and caring for people has made Volvo Cars a leader in safety." It is clear that Volvo intends for consumers to know that its aim is to assure consumers of its product's safety.

(6) B knows that A has this knowledge and intent, then, in the absence of special justification, A must do $X$ unless $B$ consents to $X$ 's not being done.

The final condition of Scanlon's account provides the key normative content to our promissory reframing. When a firm sustains, creates, or cultivates a brand, this involves generating or maintaining a series of associations. A theory of brands on the traditional view holds these associations are merely a shared set of perceptions and attitudes. On our promissory reframing, these associations also involve a shared series of normatively binding expectations. They are normatively binding, because firms voluntarily and intentionally create a series of expectations in their consumers (and prospective consumers) in a way that satisfies the principle of fidelity.

Satisfying the conditions associated with the principle of fidelity, in the case of promises, is what generates a moral obligation to fulfill the expectation generated by the promise. It is also what, as Scanlon puts it, gives the promisee a "right to rely" on what was promised (Scanlon, 1998: 305). Similarly, when companies satisfy the conditions associated with the principle of fidelity when creating, sustaining, or cultivating a brand, a firm takes on an obligation: in particular, an obligation to satisfy the expectations that, in part, constitute the brand. It is also what gives customers the moral right to rely on the expectations that constitute the brand being satisfied.

So, when Volvo creates the expectation of safety in its vehicles in a way that satisfies the principle of fidelity, Volvo now assumes an obligation to create cars that are in fact safe. Violating the expectations that constitute brands are ethically akin to breaking a promise, given that the principle of fidelity is what explains the wrongness of breaking a promise (Scanlon, 1990, 1998). Just as promises generate moral obligations to satisfy the expectations expressed through the promise, brands have a moral obligation to satisfy the expectations that are constitutive of the brand. Given that brands plausibly satisfy the principle of fidelity, we can and should understand brands as ethically akin to promises, which is to say, brands are governed by the same moral principle that governs the ethics of promises.

A few clarifications are in order. First, although consent, agreement, expectations, and other concepts linked to Scanlon's expectation theory of promises play an important role in our account and also play an important role in contract theory, we explicitly disavow our account to be understood as a legal account. This is not to say theories of promises cannot illuminate theories of contracts: as Scanlon points out, "The similarity between a promise and a contract is so obvious that it is natural to suppose that there is much to be learned about one of these notions by studying the other, or even that the legal notion of a contract can be understood by seeing it as based on the moral idea of a promise" (2001: 86). Indeed, Charles Fried's (2015) famous theory of contracts does just that-it understands contracts by way of promises. So, while promises surely can be helpful for understanding the nature of contracts, promises stand on their own. Importantly, Scanlon's theory of promises is not the same as a theory of contracts, although his account is indeed relevant to developing a theory of contracts (as he does). As he notes, "Even if... there are obvious similarities between the idea of a promise and that of a legal contract, important differences between the two notions are also apparent. While promises do not... presuppose a social institution of agreement-making, the law of contracts obviously is such an institution. Moreover, it is an institution backed by the coercive power of the state, and one that, unlike the morality of promises, is centrally concerned with what is to be done when contracts have not been fulfilled" (Scanlon, 2001: 99). The critical point for our purposes is that our promissory account of brands does not hold that brands create legal contracts with consumers; thus, our claim is not that legal obligations are generated in virtue of our account. Our promissory view is less formal and holds that brands, in virtue of satisfying the principle of fidelity, are ethically akin to promises. 
Second, our aim is not to suggest that our theory alone identifies the specific promissory content, as it were, of a given brand. We note here that there is likely heterogeneity in both brand building actions, and in consumer interpretations of those actions. Brands use various methods and forms of communication to market their products. Some of these forms may seem more like promises than others. In addition, we acknowledge that consumers may interpret various forms of communication differently and there is a fair amount of ambiguity in how branding activities are interpreted. For example, while we claim that Volvo is creating an expectation of safety, we recognize that there are likely many varying conceptions of what safety is: safer than a competitor's car, safer than flying, completely safe from any defects, etc. All of these various interpretations can create different expectations in consumer minds and hence likely have implications for whether Volvo is meeting the expectations it has created. This empirical process of detailing exactly what these expectations are is beyond the scope of this paper. Instead, we focus simply on the fact that some expectation is created by a brand that is ethically akin to a promise. We invite further research, as described more below, to empirically illuminate what exactly the details of these expectations are. In other words, we have not here exhaustively spelled out the content of the entire set of expectations that constitute Volvo's brand. Our aim has chiefly been to provide the structure of an account of brands, but one that reframes branding activity in a way that is theoretically and practically illuminating.

Third, to be sure, some (or even all) of the perceptions and attitudes surrounding a company and its offerings that the traditional view might identify with a particular brand could remain a part of the story. Some of these perceptions or attitudes might figure into, or give rise to, the normatively binding expectations. However, on our promissory reframing, we expand the singular focus of marketers on consumer perceptions and attitudes by putting at the forefront the normative enterprise of the voluntary and intentional creation of binding expectations.

Fourth, as in everyday life, one can promise to do all sorts of wrongful activities. If I promise to murder someone on behalf of a friend, this doesn't generate any reason to murder. So, for there to be moral reason to do that thing, the promise must be with respect to something that is itself morally permissible. Furthermore, the mere fact that a promise was made does not mean that one has, all things considered, reason to do that thing - there are plausibly extenuating circumstances under which promissory obligation can justifiably be overridden.

With these clarifications aside, let's turn to the advantages of a promissory account of brands. In "The Current Treatment of Brands and the Problem it Faces", we discussed a difficulty for a theory of brands when viewed exclusively through the traditional lens: it creates an explanatory problem. We will now show how adding the promissory lens to our conceptual toolkit allows for a theory of brands that avoids this problem.

\section{Remedying the Explanatory Problem}

The explanatory problem arises for the traditional view because it has difficultly explaining the presence of moralized responses in the wake of certain branding behavior, such as the moral reactive attitudes to the Nike and Gillette campaigns discussed above. Our promissory reframing of brands allows for an explanation of these moralized responses. Prior to Nike's and Gillette's brand activist campaigns, consumers would have had a reasonably stable and settled set of expectations about these companies. And both Nike and Gillette would have intentionally cultivated these expectations of their firms with careful attention through large branding teams.

The moral significance of the principle of fidelity is driven by the value of assurance. In the case of Nike and Gillette, over time, the stability of these expectations would have given consumers the assurance that they need not be on watch for the companies engaging in strong brand activism that might be at odds with consumers' personal views on the respective issues. Because consumers buy products in part to express agreement with a company's positions, their decisions of where to spend or not spend money are thought to express endorsement of a company's position (Elliott \& Wattanasuwan, 1998; Reed, 2002; Reed et al., 2012). And the stability of the expectations is what provides the value of assurance to consumers that they needn't continuously monitor a company's behavior and continually update their expectations, in order to avoid expressing endorsement of something they would not want to endorse.

Thus, on the promissory view, the recent advertisement campaigns of Nike and Gillette withdrew the assurance that a previously stable set of expectations provided. And doing so wronged their consumers, even if one accepts that the causes Nike and Gillette championed were worth supporting. It was wrong due to violating the obligation generated by the principle of fidelity, the violation of which also explains the wrong in breaking a promise. Crucially, as most contemporary scholars recognize, blame, paradigmatically expressed through indignation and resentment, is an apt response to being wronged (Coates \& Tognazzini, 2012a, 2012b; Fritz \& Miller, 2018; Hieronymi, 2004; McKenna, 2012; Priest, 2016; Scanlon, 2008; Wallace, 1994; Wallace et al., 2011). Thus, this is what explains the moralized consumer responses in the wake of these branding campaigns: consumers were wronged. 


\section{Objections}

We now consider two important objections to viewing brands through the promissory lens. First, one might point out that even in the Nike and Gillette cases, there is significant variance in consumer responses: although some were outraged by Nike and Gillette, there were plenty of consumers who were not outraged, and many who responded positively to these companies championing the cause of social justice. And this, seems to be a problem for our account: if Nike and Gillette wronged their consumers by violating a promise, why wasn't everyone outraged?

At this point, it is worth emphasizing that our framing is a decidedly normative one. We are not arguing that in every instance where there is a promissory violation we should predict moral outrage. Rather, we are arguing that brands are, ethically speaking, akin to promises, and thus, when firms violate promises, this renders appropriate the reactive attitudes, responses that are widely regarded as apt reactions to wrongdoing. So, our account simultaneously explains and justifies these responses. ${ }^{13}$

This ability to simultaneously explain and justify is not especially unique to the brand context and would be seen even in garden variety instances of promise breaking. For example, if one were to break a promise to attend a family gathering, some family members might respond with outrage, but others might simply respond with resignation, or not respond at all. But the point is that the reactive attitudes would be appropriate, not that people must respond with these attitudes or that these attitudes would be predicted. If we see someone who is outraged at a family member for breaking a promise to attend the family gathering, the broken promise is what simultaneously explains that person's response, but also justifies it.

Furthermore, the fact of the promissory violation is not the only consideration that bears on an individual's response. While the promissory violation might provide one moral reason that renders indignation apt, expressing this indignation can be outweighed by other considerations. For example, while the normatively binding expectations violated by Gillette might provide some grounds for indignation, this is not the only thing that matters to consumers. They might care more about the utilitarian features of Gillette's offerings, such as its effective razors and competitive pricing, just as well as they might care about the other corporate initiatives Gillette has pursued (e.g., environmental initiatives). Something similar is seen in ordinary cases of promise keeping. If

\footnotetext{
13 The distinction between explanation and justification is a deep and important one in a number of philosophical traditions. For more on this distinction between explanatory reasons versus justificatory reasons, in the context of reasons for action, see Alvarez's (2017).
}

I promise to pick my friend up from the airport in my Buick, but instead send a chauffeur in a Rolls-Royce limousine to pick my friend up, in a sense, I have broken my promise to my friend, but my friend might not respond with outrageindeed my friend might be elated. ${ }^{14}$

The second objection is that on a promissory account of brands, firms cannot permissibly engage in brand activism without behaving in a way that is ethically akin to violating a promise. This is not quite right. Firms can create normatively binding expectations with respect to issues related to brand activism at their inception or while they are in the early stages of building their brand. In these early stages, firms have not intentionally created a stable set of expectations. Thus, they are not making a promise with respect to any issues related to their brand activism. As long as they make clear before the stability of associations sets in, that they intend to make such political statements, they are not acting in a way akin to breaking a promise.

Indeed several firms have taken this route. The following are some examples: Patagonia, which has historically created expectations of pro-environment stances-its mission statement according to the Patagonia website (2020) is "We're in business to save our home planet"; Chick-fil-A, whose Christian foundations are clear in its self-described corporate purpose: "To glorify God by being a faithful steward of all that is entrusted to us" (Jurevicius, 2013); and Impossible Foods, which was established to directly counteract the effects of factory farming: "[U]sing animals to make meat is a prehistoric and destructive technology" (Impossible Foods, 2020a). When these companies then make

\footnotetext{
${ }^{14}$ We acknowledge that whether a specific reaction will be elicited will likely depend on a number of contextual features, including the promisee's personality, but also, importantly, the cultural and linguistic community in which the promissory act occurs. Individuals situated in some cultures may very well not respond favorably to being picked up by a chauffeur in a Rolls-Royce, in lieu of the promise being kept. So, we acknowledge that the specific promises at the center of a given brand cannot be deduced from the expectation theory of promises account alone (or from the arm chair, more generally) - rather, our aim has been to show an account of the kind of expectations that may be generated in a branding campaign and articulate the structure of how brands can be reframed as ethically akin to promises.

These ambiguities regarding expectations arise, in part, due to brands and promises often being expressed in natural rather than formal languages. So, as we know from the philosophy of language, the semantic content of natural language sentences does not alone fix the meaning of a sentence-the pragmatic content (a function of the context, intentions, tone, etc.) interacts with the semantic content to generate the meaning of a given sentence (Grice, 1989). What this means is that empiricists have an important role to play: identifying the specific contents of the given expectations will require a combination of empirical methods, including both qualitative surveys as well as empirical investigations of language use, and sociological and anthropological work regarding attitudes toward various promissory practices in different societies and cultures.
} 
statements against anti-environmental politicians, contribute to anti-gay marriage legislation, or claim that "we gotta use every tool at our disposal to eliminate the need for animal agriculture" (Impossible Foods, 2020b), respectively, they have not destabilized the normatively binding expectations they had previously created. These were the expectations from the get-go.

Of course, not all companies can or do engage in brand activism at the outset by making their moral, social, or political views clear. Our account, however, does not entirely preclude these companies from engaging in brand activism as a part of their marketing strategy, but it points to some procedural requirements. In the next section, we discuss the procedural requirements firms must satisfy when they intend to destabilize existing expectations- that is, when rebranding-including, but not limited to, when engaging in brand activism.

\section{The Procedural Requirements for Rebranding}

Under our promissory reframing, brands create expectations that are ethically akin to promises, which in turn highlights certain normative constraints on branding activities. In this section, we discuss two procedural requirements on rebranding initiatives. These procedural requirements also point to two further ways firms interested in adopting a brand activist strategy as a part of their overall marketing campaign can either permissibly do so, or do so in a less problematic way.

There are at least two ways in which firms can change course with their brands. This is by receiving consumer consent or by providing fair notice to consumers (coupled with reasons for the shift). We note that there may be other procedural ways firms can justifiably deviate from settled expectations; we only provide two. ${ }^{15}$ Future research should endeavor to explore additional possibilities.

The first route to permissibly rebranding is by requesting and receiving consumer consent. Some marketing scholars refer to this concept as "brand permission" (Meyvis \& Dhar, 2008). ${ }^{16}$ This is akin to requesting release from the promise

\footnotetext{
15 We note that there might be alternative motivations for following certain procedural requirements when rebranding, quite apart from wanting to avoid flouting the principles associated with the ethics of promising. For example, in some circumstances, the mere fact of wanting to avoid certain relationships with stakeholders being negatively affected might suffice for firms to be motivated to rebrand in an appropriate way. We thank an anonymous reviewer for drawing our attention to this point.

16 Meyvis and Dhar (2008: 23) define brand permission as "consumers' openness to considering a new brand initiative," and suggest some ways in which it can be measured.
}

of one's promissory obligation. For example, if I promise to take my friend to the airport and later ask if my friend could instead take a taxi, I have not wronged my friend insofar as my friend expresses in some way that he or she has consented to releasing me from the obligation. Firms could similarly seek consent when they seek to unsettle already stable expectations. For example, they could use consumer surveys to request permission of consumers to deviate from existing expectations. In many ways, this is exactly what marketing research does: it seeks to understand how consumers will respond to a set of activities that a firm may take. In this case, the activity is deviating from expectations. Furthermore, this is consistent with Scanlon's principle of fidelityas the sixth condition notes, "A must do $X$ unless $B$ consents to $X$ 's not being done" (emphasis added) - that holds that one is under the grip of the obligation unless the promisee consents to releasing the promiser from the obligation. Once a firm receives permission from their consumers, they can permissibly embark on the deviation in question.

So, for example, famously, Home Depot announced that it would start selling potato chips and sodas in its store in response to consumer requests. Of course, as Meyvis and Dhar (2008) acknowledge, it could have gone a step further and affirmatively received consent for its new initiative from consumers through various surveys. Likewise, in 2005, Proctor \& Gamble sought consumer consent and input when it wanted to modify certain aspects of its Crest toothpaste line (Meyvis \& Dhar, 2008). Receiving permission in this way from consumers is a way for firms to engage in rebranding initiatives without running afoul of their promissory obligations.

The second route to rebranding - deviating from the settled expectations that firms had previously intentionally cultivated-in a less problematic way involves firms giving consumers fair notice that they are withdrawing the assurance that they previously provided. ${ }^{17}$ In addition to providing such notice, firms must also provide justifiable reasons for why they are withdrawing the assurances that consumers have come to expect. This is because treating people with dignity, rather than as inanimate objects, requires giving them justifiable reasons for actions that materially affect them, a point forcefully defended in the employment

\footnotetext{
${ }^{17}$ To be sure, we recognize that providing fair notice does not, strictly speaking, release one from promissory obligations. However, as Scanlon notes, "If I am going to break my promise then it is better to warn you than not to do so, but even if I do, this is a case of breaking a promise, not fulfilling one" (1998: 301). So, while requesting and receiving consumer consent would be ideal, when this does not occur, providing fair notice is still morally preferable to rebranding without any notice at all. Relatedly, to the extent that consumers are provided fair notice and suitable reasons for the rebranding, this might, to that extent, plausibly render the moralized reactive attitude less apt.
} 
context by Werhane's (1999), Radin and Werhane's (2003), and Werhane et al. (2008).

Consider the example of WW (formerly Weight Watchers), a brand long focused on weight loss. Whether it was through exercise programs or unique diets, the company routinely touted the benefits of losing numbers on a scale. The company, however, saw that its brand was outdated, given the increase in body positivity narratives and the increase in luxury, high-end wellness programs. Subsequently, in 2018 the company sought to rebrand and change its mission. The company went from focusing on weight loss to focusing on "overall health and wellness" and "broadening the role it plays in helping everyone live healthier lives," according to a WW press release (Grossman, 2018). It even changed its name from Weight Watchers to "WW," so as to downplay the importance of losing weight and emphasize the importance of "WellnessWins." Weight Watchers released a detailed statement on September 24, 2018 that it was going to change its name and its brand on October 4, 2018. In addition to providing this notice to consumers, WW provided clear reasons throughout the press release of why it thought this shift was important: "We are committed to always being the best weight management program on the planet, but now we're putting our decades of knowledge and expertise in behavioral science to work for an even greater mission... We are becoming the world's partner in wellness. No matter what your goal is - to lose weight, eat healthier, move more, develop a positive mind-set, or all of the above-we will deliver science-based solutions that fit into people's lives" (Grossman, 2018). WW made clear that its experience with the science of losing weight and its desire to make a larger impact in more lives was the impetus for the rebrand. ${ }^{18}$

Let's now return to the issue of firms wanting to engage in brand activism as a part of their marketing campaigns, with these procedural requirements in mind. If a firm (like Nike or Gillette) already has created a stable set of normatively binding expectations, it can still permissibly deviate from these expectations by receiving consumer consent; or alternatively, if this is not possible, it can destabilize the expectations in a less problematic way by providing consumers with fair notice that is coupled with reasons. Nike or Gillette could receive consent from its consumers to undertake a new brand activism initiative and thereby permissibly unsettle already stable expectations by surveying its customers to request permission. Securing this permission would be akin to being waived from the promissory obligation.

\footnotetext{
18 In another example, Dunkin' Donuts rebranded their stores and companies to de-emphasize donuts in favor of coffee and other food items. The company announced its name change to Dunkin' in a lengthy press release dated September 25, 2018, thereby putting consumers on notice of their rebranding beginning in January 2019, and also provided their reasons for rebranding (Dunkin', 2018).
}

Alternatively, for example, Nike could give consumers fair notice that it is withdrawing the assurance that the stability of expectations provided by communicating to consumers that going forward, it will be the type of firm that will engage in brand activism by taking progressive social positions or contributing to progressive political agendas. For Nike, this could have taken the form of a public relations communication along the lines of "While consumers in the past have primarily associated us with athletics, our company is poised to take strong political positions on current issues going forward." This kind of broad communication puts the consumer on notice that the assurance of brand activist neutrality previously provided by stable expectations are no longer warranted. In other words, that the firm is not, going forward, satisfying the principle of fidelity.

But notice is not alone sufficient-it is important to provide reasons as well. In the case of Nike or Gillette, the reasons could include that the firm feels it is in a position to make a difference in some public debate, that a change in the firm's management team has created an internal desire to pursue more brand activism, amongst other reasons. Providing notice and reasons less problematically withdraws the assurances, going forward, of what consumers had come to expect.

It may seem awkward for Nike to announce that it will start engaging in brand activism without actually announcing the specific positions it will advocate. However, these sorts of broad communications are routinely used in business contexts. When companies have plans to enter new industries, embark on costly research and design, or restructure their organization, they often make general statements that put consumers on notice of these changes without going into much detail. This is to say, in the same way that firms announce potential shifts in their product lines or strategic initiatives, they can similarly announce that they intend to engage in brand activism, coupled with their reasons for doing so.

Thus, reframing brands with a promissory lens allows us to see the ways in which Nike and Gillette acted at odds with the principle of fidelity in their recent branding campaigns. This is not to say, however, that they should not have engaged in brand activism, nor that the stance they took was itself problematic. But rather that there were certain procedures they should have followed prior to taking these stances, given the normatively binding expectations that they had previously created.

\section{Reconceiving the Role of Brand Managers}

Brand managers are, broadly speaking, responsible for developing brand strategy and then executing on that strategy (Cui et al., 2014; Hankinson \& Cowking, 1997). The goal of brand managers is typically to portray the most favorable 
conception of the firm and its offerings to consumers so that they will be loyal customers of the brand. This role is often conceptualized in strictly instrumental terms; that is, the brand manager is ultimately working towards increasing revenue through consumer sales. In many ways, this flows from the traditional view of brands-if brands are just a collection of associations best described as simply perceptions and attitudes toward a company and its offerings, then the person tasked with managing the brand need only focus on creating positive associations.

By disregarding the promissory core of brands, the traditional view, we argue, leaves brand managers at the risk of overlooking the pluralistic ethical values implicated in branding activities. Even granting that the aims of branding on the traditional view can realize some normative values, the traditional view's narrow framing of brands can contribute to brand managers mistakenly forming the impression that these values are the only values in branding (or alternatively, it risks brand managers (mistakenly) interpreting their branding activities as devoid of ethical content). The promissory view of brands, however, points to an underdeveloped insight into the ethical requirements of branding: brand managers must seek to satisfy the promises implicated in their brand, not just because it will garner sales, but because branding involves creating normatively binding expectations. Branding itself is a normative endeavor. ${ }^{19}$

Consider an instance of deceptive branding. An uncontroversial moral requirement in marketing ethics is not to deceive consumers (Murphy et al., 2005). For example, consider the case of Dial soap. Dial claims their products kill $99 \%$ of bacteria. Over time, consumers have come to associate this claim with Dial's brand. As it turns out, Dial soap does not kill $99 \%$ of bacteria. Indeed, Dial is currently the subject of a class action lawsuit by consumers who claim to have been deceived into believing that their soap does kill 99\% of the bacteria (In re: Dial Complete Marketing and Sales Practice Litigation, 320 F.R.D. 326, (D. N.H. 2017)).

This kind of deceptive advertising is unethical, and in many cases illegal. However, the traditional view does not provide insight into why this sort of branding is wrong, even though most recognize that it is. By understanding the associations that constitute brands as merely a shared set of perceptions or attitudes surrounding a company and its

\footnotetext{
19 This, however, is not to say that promissory obligations are the only kinds of ethical obligations implicated in branding. Brand managers may have a range of other moral obligations associated with a variety of stakeholders that do not fall under the promissory apparatus we have characterized. Relatedly, we do not deny that brand managers may perform a range of tasks associated with the perceptions and attitudes that make up brands that are not promissory activities. We only seek here to draw attention to this particular ethical obligation that is undertheorized in branding scholarship.
}

offerings, the traditional view cannot satisfactorily explain why the creation of a false association should be a concern for consumers, brands themselves, and the marketplace at large.

On our view, whatever the legality of the matter, the wrongness of Dial's branding depends (in part) on whether they intended to create this expectation about their product (that using it will kill $99 \%$ of the bacteria) and whether they were aware that consumers formed this expectation (along with the other conditions outlined above in the discussion of the principle of fidelity). If customers did not in fact have this expectation, then it might be hyperbolic advertising, but not ethically akin to the wrong in a broken promise. On the other hand, if consumers did expect that using Dial soap would result in the killing of $99 \%$ of the bacteria on their hands (and the remaining conditions of the principle of fidelity are satisfied), then Dial's soap, in fact, not killing $99 \%$ of bacteria, would amount to the wrong in breaking a promise.

One might argue that a theory of brands need not be reframed with an ethical lens to show that this sort of behavior is impermissible. Instead, independent normative considerations like the wrongness of lying or deception can explain why brands should not lie or deceive their consumers, respectively. ${ }^{20}$ While this might be right, strictly as a matter of what is minimally required of a theory of brands, this is not, in our view, adequate. This is because it allows brand managers to mistakenly view their expertise and duties as singularly focused on cultivating a narrow set of shared perceptions and attitudes in their consumers, or worse yet, it allows managers to (mistakenly) regard their role as not being ethically laden. In other words, a narrow traditional

\footnotetext{
${ }^{20}$ Kant's famous discussion of "lying promises" also throws into sharp relief this very point of why duties not to lie or deceive, although closely related, are nevertheless distinct from promissory obligations, in virtue of the different motivational structures implicated in lying and promises. As Scanlon points out, the "dependence of the efficacy of promises on the moral prohibition against breaking them (and against making them in bad faith) is what underlies the plausibility of Kant's claim that a maxim according to which one will make a "lying promise" whenever it suits one's convenience could not even be a universal law, let alone be willed to be one" (1998: 405). He continues, "Promising is a way of getting someone to loan you money, who is otherwise unwilling to do so, only because it is generally regarded as wrong to fail to fulfill a promise and people are generally influenced by this fact. So if it were a universal law that anyone may make a promise, with no intention of fulfilling it, when this is the only way to get the money he or she needs, then promising would not in fact be a means of getting money under such circumstances... But things are crucially different in the case of lying, since the efficacy of most lies does not depend on the idea that those who tell them are constrained by a moral prohibition against lying" (Scanlon, 1998: 405). This is to say, the fact of the shared recognition of the wrongness of breaking a promise plays an important role in efficacy of promissory practices in a way that is distinct from lying more generally.
} 
view of brands, risks brand managers having blinders to the normative requirements that constrain branding.

Since promissory practices are widely recognized as being ethically infused, supplementing the traditional view of brands with a promissory core allows for managers to better realize their role as one that is a decidedly normative endeavor. Although even the acts of cultivating perceptions and attitudes in consumers may realize important normative values, our promissory account brings to the forefront that there is more to the story. In particular, once we recognize that brands are ethically akin to promises, brand managers must recognize that it is not a separate question of whether they should pay attention to ethics (Freeman, 1984); rather, the activity of branding itself requires paying attention to ethics.

\section{Brand Managers and PR Crises}

Promises are morally significant and should not be taken lightly. This means that when issuing promises, including by way of branding, one should be careful what promises one chooses to make and not make promises haphazardly. This fact has implications for brand managers at a time when they may be most inclined to perform significant shifts in their branding: in response to a PR crisis. Let's consider the example of Blackwater.

The United States hired Blackwater for training and support during the 2003 Iraq War. In reality, Blackwater employees waterboarded and demeaned prisoners of war and perpetrated other human rights violations (Gorman, 2008; Hudson, 2012; Roberts, 2014). Blackwater's nefarious activities went unnoticed for a significant period of time, during which Blackwater was able to enjoy significant economic successes (Fisher, 2010). In 2006, news reporters leaked information about Blackwater's activities. The company quickly became affiliated with war crimes, illegal activity, and human rights violations (Roberts, 2014)—in short, Blackwater faced a PR crisis.

Blackwater sought to rebrand in the wake of this PR crisis. Wanting to rebrand in the wake of a PR crisis is understandable. How did Blackwater rebrand? Blackwater changed its name to "Xe Services". Once people learned that Xe Services was simply a different name for the same firm, they again changed their name, this time to "Academi" (Hudson, 2012).

Many have an intuitive aversion to Blackwater's blatant attempts to avoid negative PR repercussions and skirt accountability through changing merely their name. However, the traditional view does not caution brand managers from undertaking these kinds of rebranding efforts. This is because on the traditional view's framing of brands, the brand manager's role could simply be to add a new firm to their consumers' minds-for example, by renaming
Blackwater to "Xe Services"- that has a new set of perceptions or attitudes. But why this way of rebranding would be inappropriate is not at all clear on the traditional view.

On the other hand, on our promissory reframing, managers must recognize that branding is normatively significant and thus should not be taken lightly. Notably, when rebranding, the new expectations the firm seeks to cultivate must correspond to material changes in the company's actions, behavior, and products that warrant the new expectations. Blackwater, however, did not fundamentally change the actions, behaviors, or products, that would render these changes in expectations warranted. Rather they attempted to avoid the negative PR repercussions merely by changing their name, thereby not taking the promise making activity seriously.

In contrast, consider McDonald's' attempt to rebrand in the wake of the Super Size Me documentary, which drew attention to the poor nutritional value of McDonald's' products. If McDonald's simply tried to rebrand by attempting to generate healthy associations by painting its golden arches green, this would be inappropriate on our account. But, in fact, McDonald's rebranded by updating consumer associations that were focused more on health and wellness by enacting material changes to warrant the new expectations, including introducing salads and healthy wraps to its menu, and providing caloric and nutritional information about its existing items.

Returning to the case of Blackwater, we are not claiming that on our account that it should not have rebranded. Rather we are claiming that, when rebranding, Blackwater should have changed its actions to actually be in line with the new expectations that it intended to create. This certainly would have taken time, as consumer expectations tend to be inelastic, and this inelasticity should have been taken seriously in its own right. Therefore, creating new associations for Blackwater would likely have taken time, effort, and firm level actions, given the existing negative associations that consumers had formed.

One surprising source of guidance for how to permissibly rebrand comes from the scholarship on hypocritical blaming (Cohen, 2006; Friedman, 2013; Fritz \& Miller, 2018; Scanlon, 2008; Smith, 2007; Wallace, 2010). Hypocritical blaming occurs when one blames another for a wrongdoing one has oneself previously perpetrated. While most contemporary scholars regard hypocritical blaming as inappropriate, most also recognize that it cannot be the case that one can never blame another for similar actions to what one previously performed. Instead, in order to blame another for the same sort of offense that one has committed in the past, one needs to acknowledge one's fault, disavow one's past behavior, reform one's behavior, and so on. Only then can one permissibly blame another for a wrongdoing that one has perpetrated in the past. 
Rebranding in the wake of a PR crisis is similar in that, to distance oneself from previous wrongdoing, one must disavow previous actions, take responsibility, and pursue substantive actions to justify the change in expectations that the firm wishes to induce. Blackwater could have done this first by publicly apologizing and acknowledging the wrongness of its actions as well as committing to avoiding such wrong actions going forward. This would have entailed actions such as communicating to consumers the changes in policies and procedures it would undertake to prevent reoccurrence of similar wrongs, firing senior officials who authorized these wrongs, as well as firing lower-level individuals who perpetrated these wrongs. It also might have involved symbolic gestures such as donations to organizations involved in remedying human rights violations.

The crucial point is this: our promissory lens allows brand managers to more readily attend to the ethical requirements that constrain branding - this is because ethical requirements are front and center when the promissory core of brands is recognized. Because of the moral significance of promises, brand managers are better positioned to view themselves as embarking on an activity that is a decidedly normative endeavor and to see their role as being inextricably tied to ethics.

\section{Future Avenues of Research}

Our account of brand as promise opens up several new avenues of research for marketing and business ethics scholars. First, our promissory account of brands suggests the importance of measuring a commonly overlooked construct in branding scholarship-the expectations consumers have of a company and its offerings. Traditionally, brand scholars have measured what a firm's brand is by asking consumers what associations are triggered when thinking of a company and its offerings (Keller, 1993; Schmitt, 2012). Given our promissory reframing, rather than primarily asking consumers what associations come to mind when they think of a firm, future empirical research should also ask consumers about their expectations of a company and its offerings. This can potentially be accomplished by blending behavioral ethics methods that measure promising norms (Cropanzano \& Stein, 2009) with more traditional brand measurement survey methods (Keller, 1993; Schmitt, 2012).

Second, our account can assist marketing researchers in their efforts to better understand the distinctive moralized consumer responses associated with brand activism. While marketing scholarship has catalogued the range of moralized consumers responses to brand activism (Fitzgerald \& Donovan, 2018; Korschun et al., 2016), it has yet to systematically explore the rationales for these responses and what actions companies can take to mitigate these moralized responses. Our promissory account points to a specific rationale hypothesis: that consumers feel they have been wronged. And to a specific mitigation hypothesis: how pursuing the procedural requirements articulated above can lessen the vigor of the responses. Various consumer studies could manipulate firm information using vignettes to test these hypotheses to assess why consumers react the way they do and if changes in procedures do, in fact, change these responses.

Third, there are additional questions our account points to that arise in virtue of technological advances. As social media plays an increasingly significant role in branding, some firms encourage their employees to serve as brand ambassadors on social media (Bhargava \& Velasquez, 2020; Cervellon \& Lirio, 2017; Bedi, 2016). For example, firms might encourage employees to post about their experiences with products the company offers, workplace social events, and even the firm's social responsibility initiatives. When firms encourage their employees to serve as brand ambassadors, to what extent are firms responsible for fulfilling the expectations created by these employees?

Fourth, and relatedly, while in this article we have focused on the normatively binding expectations firms create in relation to customers, a significant portion of branding activities involve internal branding directed at employees. For example, firms might create an expectation that perspective employees will be joining a firm that values sustainability and diversity. Employees, unlike consumers, may rely more heavily on the expectations companies create because they may leave a well-paying job, relocate, or even change industries to work for another company. How, if at all, does this bear on the significance of the promissory obligations associated with a firm's internal branding?

Fifth, our account creates new questions with respect to so-called umbrella brands. Large holding companies have several disparate and often unrelated sub brands that operate more or less independently. What are the obligations of the holding company when these sub brands create promises that conflict with each other? For example, a conglomerate may have a sub-brand that seeks to create expectations of having kid friendly meals (e.g. macaroni and cheese), while at the same time another sub-brand that creates expectations of harmful products (e.g. cigarettes). This creates competing expectations for customers at the conglomerate brand level but not necessarily at the sub brand level. How should the umbrella brand reconcile these disparate expectations without upsetting customers when they inevitably find out that the umbrella brand has made conflicting promises?

Sixth, what actions can a firm permissibly take in service of sustaining its brand? Sometimes, firms fire employees who have made inappropriate remarks, even in cases where 
these inappropriate remarks were made when off-duty, in order to avoid a brand crisis (Bhargava, 2020)-is this appropriate? In other words, scholars should explore what actions are permissible to undertake in seeking to fulfill a brand promise.

\section{Conclusion}

Brands have historically been viewed as a constellation of shared associations surrounding a company and its offerings. On the traditional view of brands, these associations are interpreted as perceptions and attitudes in consumers' minds in relation to a company and its offerings. We argued that this framing is incomplete and faces an important difficulty: an explanatory problem. Specifically, the traditional view is unable to satisfactorily explain why certain branding activism initiatives elicit the moralized reactive attitudes that are paradigmatic responses to wrongdoing. We argued that this explanatory problem can be avoided by reframing brands as a series of normatively binding expectations that are ethically akin to promises. Our promissory account of brands illuminates a number of ethical requirements on branding, and reconceptualizes the role of a brand manager.

Acknowledgements We thank Vivek Astvansh, Matthew Caulfield, David Reibstein, Ike Silver, and Matthew Turk for their helpful comments, feedback, and conversation. We are also grateful to the editor and three anonymous reviewers for their helpful feedback.

\section{Declarations}

Conflict of interest The authors declare that they have no conflict of interest.

Ethical Approval This article does not contain any studies with human participants or animals performed by the author.

Open Access This article is licensed under a Creative Commons Attribution 4.0 International License, which permits use, sharing, adaptation, distribution and reproduction in any medium or format, as long as you give appropriate credit to the original author(s) and the source, provide a link to the Creative Commons licence, and indicate if changes were made. The images or other third party material in this article are included in the article's Creative Commons licence, unless indicated otherwise in a credit line to the material. If material is not included in the article's Creative Commons licence and your intended use is not permitted by statutory regulation or exceeds the permitted use, you will need to obtain permission directly from the copyright holder. To view a copy of this licence, visit http://creativecommons.org/licenses/by/4.0/.

\section{References}

Aaker, D. A. (1991). Managing brand equity. The Free Press.
Abela, A. V., \& Murphy, P. E. (2008). Marketing with integrity: Ethics and the service-dominant logic for marketing. Journal of the Academy of Marketing Science, 36(1), 39-53

Agarwal, M. K., \& Rao, V. R. (1996). An empirical comparison of consumer-based measures of brand equity. Marketing Letters, 7(3), 237-247

Alvarez, M. 2017. Reasons for Action: Justification, Motivation, Explanation. In E. N. Zalta (Ed.), The Stanford Encyclopedia of Philosophy.

Anker, T., Kappel, K., Eadie, D., \& Sandoe, P. (2012). Fuzzy promises: explicative definitions of brand promise delivery. Marketing Theory, 12, 267-287

Barney, J. B. (2014). How marketing scholars might help address issues in resource-based theory. Journal of the Academy of Marketing Science, 42(1), 24-26

Bedi, S. (2016). Fully and barely clothed: Case studies in gender and religious discrimination in the wake of Citizens United and Hobby Lobby. Hastings Business Law Journal, 12(2).

Bhargava, V. R. (2020). Firm responses to mass outrage: Technology, blame, and employment. Journal of Business Ethics, 163(3), $379-400$

Bhargava, V. R., \& Velasquez, M. (2020). Ethics of the attention economy: The problem of social media addiction. Business Ethics Quarterly. https://doi.org/10.1017/beq.2020.32

Boush, D. M., Friestad, M., \& Rose, G. M. (1994). Adolescent kkepticism toward tv advertising and knowledge of advertiser tactics. Journal of Consumer Research, 21(1), 165-175

Calfee, J. E., \& Ringold, D. J. (1994). The 70\% majority: Enduring consumer beliefs about advertising. Journal of Public Policy \& Marketing, 13(2), 228-238

Cervellon, M. C., \& Lirio, P. (2017). When employees don't "like" their employers on social media. MIT Sloan Management Review, $58(2), 63-70$

Change, J. W. (2002). Will a family brand image be diluted by an unfavorable brand extension? A brand trial-based approach. Advances in Consumer Research, 29(1), 299-304

Cheng, S. Y. Y., White, T. B., \& Chaplin, L. N. (2012). The effects of self-brand connections on responses to brand failure: A new look at the consumer-brand relationship. Journal of Consumer Psychology, 22(2), 280-288

Coates, D. J., \& Tognazzini, N. A. (2012a). The nature and ethics of blame. Philosophy Compass, 3, 197-207

Coates, D. J., \& Tognazzini, N. A. (2012b). Blame: Its nature and norms. Oxford University Press.

Cohen, G. (2006). Casting the first stone: Who can, and who can't, condemn the terrorists? Royal Institute of Philosophy Supplement, 58, 113-136

Cohon, R. (2006). Hume on promises and the peculiar act of the mind. Journal of the History of Philosophy, 44(1), 25-45

Cohon, R. (2020). Hume's practice theory of promises and its dissimilar descendants. Synthese. https://doi.org/10.1007/ s11229-020-02684-2

Coulter, R. A., Zaltman, G., \& Coulter, K. S. (2001). Interpreting consumer perceptions of advertising: An application of the zaltman metaphor elicitation technique. Journal of Advertising, 30(4), $1-21$

Cropanzano, R., \& Stein, J. (2009). Organizational justice and behavioral ethics: promises and prospects. Business Ethics Quarterly, $19,193-233$

Cui, A. P., Hu, M. Y., \& Griffith, D. A. (2014). What makes a brand manager effective? Journal of Business Research, 67(2), 144-150

Darwall, S. (2009). The second-person standpoint. Harvard University Press.

Dawar, N., \& Lei, J. (2009). Brand crises: The roles of brand familiarity and crisis relevance in determining the impact on brand evaluations. Journal of Business Research, 62(4), 509-516 
Deigh, J. (2002). Promises under fire. Ethics, 112(3), 483-506

Draper, K., \& Creswell, J. 2019. Colin Kaepernick "dream crazy" ad wins Nike an Emmy. The New York Times.

Dunfee, T. W., Smith, N. C., \& Ross, W. T. (1999). Social contracts and marketing ethics. Journal of Marketing, 63(3), 14-32

Dunkin. 2018. Welcome to Dunkin': Dunkin' Donuts reveals new brand identity.

Elliott, R., \& Wattanasuwan, K. (1998). Brands as symbolic resources for the construction of identity. International Journal of Advertising, 17(2), 131-144

Farris, P. W., Bendle, N., Pfeifer, P. E., \& Reibstein, D. (2010). Marketing metrics: The definitive guide to measuring marketing performance. New York: Pearson Education.

Fisher, M. 2010. Blackwater put up for sale. The Atlantic.

Fitzgerald, M. P., \& Donovan, K. R. (2018). Consumer responses to for-profit firms exercising religious freedom in the marketplace. Journal of Public Policy \& Marketing, 37(1), 39-54

Freeman, R. E. (1984). Strategic management. Cambridge University Press.

Fried, C. (2015). Contract as promise: A theory of contractual obligation. Oxford University Press.

Friedman, M. (2013). How to blame people responsibly. Journal of Value Inquiry, 47(3), 271

Friestad, M., \& Wright, P. (1995). Persuasion knowledge: lay people's and researchers' beliefs about the psychology of advertising. Journal of Consumer Research, 22(1), 62-74

Fritz, K. G., \& Miller, D. (2018). Hypocrisy and the standing to blame. Pacific Philosophical Quarterly, 99(1), 118-139

Gay, J. 2018. Colin Kaepernick and Nike, starring you and me. The Wall Street Journal.

Gilbert, M. (1993). Is an agreement an exchange of promises? The Journal of Philosophy, 90(12), 627-649

Gilbert, M. (2013). Three dogmas about promising. Joint commitment: How we make the social world. Oxford University Press.

Gilette. 2019. Gillette.com. Retrieved from, https://gillette.com/en-us/ about/the-best-men-can-be\%0A.

Gorman, S. 2008. CIA likely let contractors perform waterboarding. The Wall Street Journal.

Grice, H. P. (1989). Logic and conversation. Studies in the way of words. (pp. 22-40). Harvard University Press.

Griner, D. 2018. Nike's Kaepernick ad immediately sparks outrage, adoration and satire. Adweek.

Grossman, M. 2018. WW Press Release. WW Website.

Habib, A. 2018. Promises. In E. N. Zalta (Ed.), The Stanford Encyclopedia of Philosophy.

Hankinson, G., \& Cowking, P. (1997). Branding in practice: The profile and role of brand managers in the UK. Journal of Marketing Management, 13(4), 239-264

Herzog, H. (1963). Behavioral science concepts for analyzing the consumer. Marketing and the Behavioral Sciences, 3, 76-86

Heuer, U. (2012a). Promising-part 1. Philosophy Compass, 7(12), $832-841$

Heuer, U. (2012b). Promising-part 2. Philosophy Compass, 7(12), $842-851$

Hieronymi, P. (2004). The force and fairness of blame. Philosophical Perspectives, 18(1), 115-148

Hosein, A. (2019). The ethics of migration: An introduction. Routledge.

Hudson, J. 2012. Time for blackwater to change its name again. The Atlantic.

Hume, D., Selby-Bigge, L. A., \& Nidditch, P. H. (Eds.). (2001). A treatise of human nature. (2nd ed.). Clarendon Press.

Impossible Foods. 2020a. Impossible Foods mission. Retrieved from, https://impossiblefoods.com/mission/.

Impossible Foods. 2020b. @ImpossibleFoods. Twitter. Retrieved from, https://twitter.com/ImpossibleFoods/status/1228563501 070741504
International Organization for Standardization. 2019. Brand evaluation-principles and fundamentals (ISO Standard No. 20671). https://www.iso.org/standard/68786.html.

Jean, J. 2015. How Disney built an empire by designing brand experience. Zilliondesigns. Retrieved from, https://www.zilliondesigns. $\mathrm{com} / \mathrm{blog} /$ disney-brand-experience/

Jurevicius, O. 2013. Mission statement of Chick-fil-A. Strategic Management Insight.

Keller, K. L. (1993). Conceptualizing, measuring, and managing customer-based brand equity. Journal of Marketing, 57(1), 1-22

Keller, K. L. (2003). Understanding brands, branding and brand equity. Interactive Marketing, 5(1), 7-20

Keller, K. L., \& Lehmann, D. R. (2006). Brands and branding: Research findings and future priorities. Marketing Science, 25(6), 740-759

Knapp, D. E. (2000). The brand mindset. McGraw-Hill.

Kolodny, N., \& Wallace, R. J. (2003). Promises and practices revisited. Philosophy \& Public Affairs, 31(2), 119-154

Korschun, D., Aggarwal, A., \& Rafieian, H. (2016). Taking a stand: Consumer responses to corporate political activism. SSRN Electronic Journal. https://doi.org/10.2139/ssrn.2806476

Kotler, P. H. (1991). Marketing management. Prentice-Hall Inc.

Krishnan, H. S. (1996). Characteristics of memory associations: A consumer-based brand equity perspective. International Journal of Research in Marketing, 13(4), 389-405

Laczniak, G. R., \& Murphy, P. E. (2019). The role of normative marketing ethics. Journal of Business Research, 95, 401-407

Levitt, T. (1981). Marketing intangible products and product intagibles. Harvard Business Review, 59, 94-102

Mason, E. (2005). We make no promises. Philosophical Studies, $123(1 / 2), 33-46$

Mather, V. 2019. A timeline of Colin Kaepernick vs. the N.F.L. The New York Times.

Mats, U. (2003). Core value-based corporate brand building. European Journal of Marketing, 37(7/8), 1017-1040

McKenna, M. (2012). Conversation and responsibility. Oxford University Press.

Meyvis, T., \& Dhar, R. (2008). Brand permission: A conceptual and managerial framework. Handbook on brand and experience management. (pp. 18-34). Edward Elgar.

Morgan, P. 2019. @ PiersMorgan. Twitter. Retrieved from https://twitt er.com/piersmorgan/status/1084891133757587456?lang=en.

Murphy, P. E., Laczniak, G. R., Bowie, N. E., \& Klein, T. A. (2005). Ethical marketing. Pearson Education Inc.

Newman, J. W. (1957). New insight, new progress, for marketing. Harvard Business Review, 35(6), 95-102

Novosedlik, W. n.d. Promise: what a brand promise is and why it matters. MaRS.

Owens, D. (2006). A simple theory of promising. The Philosophical Review, 115(1), 51-77

Owens, D. (2007). Duress, deception, and the validity of a promise. Mind, 116(462), 293-315

Owens, D. (2008). Promising without Intending. The Journal of Philosophy, 105(12), 737-755

Patagonia. 2020. Core values. Retrieved from, https://www.patagonia. com/core-values/.

Pearson, B. (2006). Life is not a shopping cart: Building brands'. Journal of Consumer Marketing, 23(7), 385-386

Petty, R. E., \& Cacioppo, J. T. (1986). The elaboration likelihood model of persuasion. In R. E. Petty \& J. T. Cacioppo (Eds.), Communication and persuasion. (pp. 1-24). Springer.

Pimentel, B. 2007. A brand is a promise to a customer. Stanford Graduate School of Business.

Priest, M. (2016). Blame after forgiveness. Ethical Theory and Moral Practice, 19(3), 619-633

Punjaisri, K., \& Wilson, A. (2017). The role of internal branding in the delivery of employee brand promise. In J. M. T. Balmer, S. 
M. Powell, J. Kernstock, \& T. O. Brexendort (Eds.), Advances in corporate branding. (pp. 91-108). Springer.

Radin, T. J., \& Werhane, P. H. (2003). Employment-at-will, employee rights, and future directions for employment. Business Ethics Quarterly, 13(2), 113-130

Ravi, P., Quester, P. G., \& Cooksey, R. W. (2005). Consumer-based brand equity: Improving the measurement-empirical evidence. Journal of Product \& Brand Management, 14(3), 143-154

Rawls, J. (1955). Two concepts of rules. The Philosophical Review, 64(1), 3-32

Rawls, J. (1999). A theory of justice (Revised). The Belknap Press of Harvard University Press.

Reed, A. (2002). Social identity as a useful perspective for self-conceptbased consumer research. Psychology \& Marketing, 19(3), 235-266

Reed, A., Forehand, M. R., Puntoni, S., \& Warlop, L. (2012). Identitybased consumer behavior. International Journal of Research in Marketing, 29(4), 310-321

Roberts, D. 2014. US jury convincts Blackwater guardes in 2007 killing of Iraqi civilians. The Guardian.

Sarkar, C., \& Kotler, P. 2018. Stand for something: brand activism at Nike. The Marketing Journal.

Satell, G. 2010. A brand is a promise. Digital Tonto.

Scanlon, T. (1990). Promises and practices. Philosophy \& Public Affairs, 1990, 199-226

Scanlon, T. M. (1998). What we owe to each other. The Belknap Press of Harvard University Press.

Scanlon, T. M. (2001). Promises and contracts. In P. Benson (Ed.), The theory of contract law: New essays. (pp. 86-117). Cambridge University Press.

Scanlon, T. (2008). Moral dimensions: Permissibility, meaning. Belknap Press of Harvard University Press.

Schmitt, B. (2012). The consumer psychology of brands. Journal of Consumer Psychology, 22(1), 7-17

Sheinman, H. (2011). Promises and agreements: Philosophical essays. Oxford University Press.

Shiffrin, S. V. (2008). Promising, intimate relationships, and conventionalism. Philosophical Review, 117(4), 481-524

Sjödin, H., \& Törn, F. (2006). When communication challenges brand associations: A framework for understanding consumer responses to brand image incongruity. Journal of Consumer Behaviour, 5(1), 32-42
Smith, A. (2007). On being responsible and holding responsible. The Journal of Ethics, 11(4), 465-484

Smith, N. C. (1995). Marketing strategies for the ethics era. Sloan Management Review, 36, 85

Soh, H., Reid, L. N., \& King, K. W. (2009). Measuring trust in advertising. Journal of Advertising, 38(2), 83-104

Strawson, P. F. (1962). Freedom and resentment. Proceedings of the British Academy, 48, 1-25

Sulmasy, D. P. (1999). what is an oath and why should a physician swear one? Theoretical Medicine and Bioethics, 20(4), 329-346

Sürücü, Ö., Öztürk, Y., Okumus, F., \& Bilgihan, A. (2019). Brand awareness, image, physical quality and employee behavior as building blocks of customer-based brand equity: Consequences in the hotel context. Journal of Hospitality and Tourism Management, 40, 114-124

Tilley, C. (1999). Built-in branding: How to engineer a leadership brand. Journal of Marketing Management, 15(1-3), 181-191

Topping, A., Lyons, K., \& Weaver, M. 2019. Gillette \#metoo razors ad on "toxic masculinity" gets praise-and abuse. The Guardian.

Trump, R. K. (2014). Connected consumers' responses to negative brand actions: The roles of transgression self-relevance and domain. Journal of Business Research, 67(9), 1824-1830

Tuomela, R. (2013). Cooperation: A philosophical study. Kluwer Academic Publishers.

Volvo Group. 2019. The Volvo Group. Retrieved from, https://www. volvogroup.com/

Wallace, R. J. (1994). Responsibility and the moral sentiments. Harvard University Press.

Wallace, R. J. (2010). Hypocrisy, moral address, and the equal standing of persons. Philosophy and Public Affairs, 38(4), 307-341

Wallace, R. J., Kumar, R., \& Freeman, S. (2011). Dispassionate opprobrium: On blame and the reactive sentiments. Reasons and recognition: Essays on the philosophy of TM scanlon.Oxford University Press.

Watson, G. (2004). Asserting and promising. Philosophical Studies, $117(1 / 2), 57-77$

Werhane, P. H. (1999). Justice and trust. Journal of Business Ethics, $21,237-249$

Werhane, P., Radin, T. J., \& Bowie, N. E. (2008). Employment and employee rights. Wiley.

Publisher's Note Springer Nature remains neutral with regard to jurisdictional claims in published maps and institutional affiliations. 